\title{
Editorial
}

\section{The Fragility of Christian Unity and the Lambeth Conference 1920 and 2021}

\author{
Paul Avis \\ Honorary Professor, Department of Theology and Religion, Durham \\ University, Durham, UK; Honorary Research Fellow, Department of \\ Theology and Religion, University of Exeter, Exeter, UK \\ dr.paul.avis@gmail.com
}

In this issue of Ecclesiology four substantial articles, by renowned experts in the field, are devoted to the critical study of the great Lambeth Conference of 1920 and to its landmark 'Appeal to All Christian People' which has resounded through the annals of ecumenical endeavour ever since. In looking back to that significant Anglican initiative of a century ago (which was preceded, earlier in the same year, by the remarkable Encyclical on unity of the Ecumenical Patriarchate, 'To the Churches of Christ Everywhere'), this issue, including the present Editorial, also looks forward to the next Lambeth Conference, originally scheduled for Summer 2020 and now postponed to 2021, and at the same time includes some reflection on the present state of - and future hopes for the worldwide Anglican Communion.

In late 2017 Benjamin M. Guyer and I published an edited volume of essays that looked in some depth and breadth at the Lambeth Conference as a significant institution of the Anglican Communion. ${ }^{1}$ Ben Guyer's chapter was devoted to the issues raised by the Royal Supremacy of the British Crown for the

1 Paul Avis and Benjamin M. Guyer (eds), The Lambeth Conference: Theology, History, Polity and Purpose (London and New York: Bloomsbury T\&T Clark, 2017), with a commendation by the Archbishop of Canterbury, The Most Reverend and Right Honorable Justin Welby. 
authority of the (first) Lambeth Conference and my chapter concerned the relationship between the Archbishop of Canterbury and the Lambeth Conference as expressed through successive gatherings of the Anglican bishops. As editors we were disappointed that several senior persons from the 'Global South' of Anglicanism, whom we had expected to contribute, did not in the end do so - hence some reviewers have pointed out that the book includes only one chapter from a 'Global South' or GAFCON (Global Anglican Futures Conference) perspective. Putting together the reflections generated by editing and contributing to that work with thoughts suggested by the theme and articles of this issue leads me to offer a number of brief pointers to the nature of the Lambeth Conference (which from now on in this Editorial I will abbreviate to LC) and the work that it is designed to do in the merciful providence of God. As I must keep these points brief for the purposes of an Editorial, I have footnoted a few places where they can be followed up by anyone who might wish to do so.

1. The LC should not be regarded as a 'one-off' or ad hoc gathering of bishops, an event that happens to pop up from time to time in the history of Anglicanism. Rather, it should be seen as an enduring institution of the Anglican Communion, having continued in existence for 150 years (the next Conference will be the fifteenth). In fact, I would argue, the LC is the most important Anglican institution that there is or ever has been. The LC is more significant ecclesiologically (that is, for our understanding of the nature and mission of Christ's church) than the comparatively recent Primates' Meeting of senior archbishops and metropolitans which - though it seems not always to have been aware of this - lacks any executive authority as far as the Anglican Communion as a whole is concerned. The LC is also more significant ecclesiologically than the Anglican Consultative Council (which is entirely necessary but is constitutionally limited in the scope of its responsibilities). And the LC has greater ecclesiological import than the office and ministry of the Archbishop of Canterbury. The ministry of the Archbishop largely owes its standing on the international, and even the national, stage to the fact that it was the Archbishop of Canterbury, Charles Thomas Longley, who took the initiative of inviting the bishops of the Anglican churches to gather, under his presidency, for the discussion of common problems. Of the four designated 'Instruments of Communion', the LC expresses and instantiates that communion most clearly. ${ }^{2}$ As the most

2 See Towards a Symphony of Instruments: A Historical and Theological Consideration of the Instruments of Communion of the Anglican Communion; A Working Paper prepared by The Inter-Anglican Standing Commission on Unity, Faith and Order (London: Anglican Consultative Council, 2015); Stephen Pickard, 'The Lambeth Conference among the Instruments of Communion', in Avis and Guyer (eds), The Lambeth Conference, Chapter 1; Paul Avis, 
significant and enduring of the four 'Instruments', with implications for the ecclesial dimension of the Anglican Communion, the LC should be referred to not as 'a Lambeth Conference' (as in 'in such and such a year the Archbishop of Canterbury convened a Lambeth Conference', but as 'the Lambeth Conference 1920' or 'the Lambeth Conference 2021'.

2. Why do I claim that the LC is the most ecclesiologically significant of the Instruments of Communion? The other three 'Instruments' are contingent to varying degrees; they need not have come about at all, in one sense, or exist in their present form today. The Primates' Meeting is about forty years old, having been agreed by the member churches of the Communion at the initiative of Archbishop Donald Coggan in 1978. The tasks of the Anglican Consultative Council could possibly be carried out by a differently structured and constituted body, provided that the member churches agreed about that. And it is not, of course, by any sort of divine right that the Archbishop of Canterbury presides in the other three Instruments, though it is fitting that the incumbent for the time being of the most ancient English metropolitical See should have that role. Episcopacy, on the other hand, is an institution that comes down to us from the apostolic or early post-apostolic age, was universal in the church from the second to the sixteenth century, now prevails in the traditions of more than one and half billion Christians, and is widely recognised ecumenically as the form of oversight that should characterise a united church of the future. Oversight (episkope) is an intrinsic element of the church of Christ and, in one form or another, of all churches. By virtue of their ordination and appointment bishops must exercise their ministry of oversight and one important way in which they do this is by modelling collegially the unity of the church. A college must gather together, for the episcopate has a collective or corporate role, as well an an individual or personal one, and such gatherings are a major plank of the conciliar life of the church. So, if the LC did not exist, it would be necessary to invent it by any other name. I suggest that it is the 'least contingent', the most theologically solid, of the Instruments.

3. It is immensely significant that the LC is a conference of bishops - of all serving bishops, as far as possible, of the Anglican Communion, who by virtue of their office in member churches of the Anglican Communion, are required to be in communion themselves with the See of Canterbury. While the bishops are supported by administrative staff, and although there are theologians

'Anglican Conciliarism', in Mark D. Chapman, Sathianathan Clarke and Martyn Percy (eds), The Oxford Handbook of Anglican Studies (Oxford: Oxford University Press, 2015), Chapter 3. 
(I trust) and other specialists on hand to advise as appropriate, the Conference is constituted by bishops as chief pastors in the Church of God, that is to say those who are ordained to the responsibility of being guardians of the faith, sacraments and ministry of the Church. Bishops are also the most representative Christian ministers, since they incorporate in themselves the callings of the baptised faithful, the diaconate and the priesthood. There is a sense in which they bring their dioceses with them to the LC, represent the concerns and needs of their diocese, receive the support, counsel and prayers of their fellow bishops, and take back to their dioceses, on their return, wisdom and encouragement received from the Conference. ${ }^{3}$

4. Although the LC, from its inception in 1867 , has been designated consistently as a 'conference', rather than as a synod or council, it is in truth a genuine expression of the conciliar nature of the Christian church. Conciliarity (or synodality) is a constitutive and irreplaceable dimension of the church considered as a communion in the Holy Spirit (koinonia, communio, sobornost) and as the Spirit-bearing Body of Christ. The principle of conciliarity stands for the whole church taking responsibility corporately for its life and mission, by gathering representatively in council for the purposes of prayer and worship, Bible study, conference, discernment, reception of true insights as they emerge, and guidance to the faithful on the pressing issues of the time. The LC cannot decide anything for the Anglican Communion; it does not have legislative authority and issues no canons. Does this disqualify it as a synod or council of the church? Does its lack of teeth undermine its credentials as an authentic expression of conciliarity? Some have argued that it does. Not a few Anglicans have clamoured for the LC to lay down the law for the Communion, resolve differences and re-establish unity. I have argued that such a course is neither possible nor desirable. Let us compare with the LC the Second Vatican Council of 1962-1965, and the various Synods of Bishops convened in recent years and decades by the Pope, and the Holy and Great Council of the Orthodox Churches held in Crete in 2016. Not one of these conciliar gatherings legislated for the church, issued canons or (as councils traditionally did) pronounced anathemas on those who disputed their decisions. These events were all primarily deliberative gatherings, established in a pastoral mode. Their task and function was above all to ponder Christian truth and communicate it in ways adapted to the modern world - that is to say, by an attractive, eloquent presentation and by argued and reasoned persuasion, making a cogent and

3 Cf. Paul Avis, Becoming a Bishop: A Theological Handbook of Episcopal Ministry (London and New York: Bloomsbury T\&T Clark, 2015). 
convincing case, rather than by laying down the law on pain of spiritual punishment.

5. The LC fits this picture perfectly. Although, as I have said, Anglicans and others sometimes bewail the fact that the LC lacks legislative teeth that would enable it to knock the Anglican Communion into shape, the lack of executive authority is a blessing in disguise. The Anglican Communion is not a global church and is not constituted to perform that role. It is made up of selfgoverning national or regional churches (sometimes misleadingly called 'provinces') that recognise that they are historically, theologically and liturgically interdependent, though also bound together by many less formal ties - 'bonds of affection', as they are sometimes called. The Anglican Communion does not have a common liturgy (though there are strong family resemblances and a common root in the Book of Common Prayer, variously adapted); ${ }^{4}$ nor does it possess a single body of canon law (though it has been shown that there is a remarkable degree of consensus among the canons of the member churches). ${ }^{5}$ Each member church needs to evaluate the advice and recommendations (if any) of the LC through its own structures of study, discernment and decisionmaking. The Anglican Communion coheres (in so far as it does) through patient discussion and slow processes of discernment or reception, waiting upon a common mind and exercising restraint until that is discovered (or revealed). By its very nature, the Communion has to wait upon consensus. Its polity is ultimately one of persuasion not prescription. ${ }^{6}$

6. Finally, we cannot evade the fact that the current divisions between the churches of the Anglican Communion mean that some churches will not be represented, or not fully represented, at the next LC. There is an ancient saying that the devils in hell rejoice when a church council is announced because they see plenty of opportunities to get busy with their hellish work. The divisions within the Anglican Communion are ostensibly over gender roles in ministry and questions of human sexuality; but, more profoundly, they are divisions over biblical interpretation and its significance for the formation of

4 See Paul Avis, 'The Book of Common Prayer and Anglicanism', in Stephen Platten and Christopher Woods (eds), Comfortable Words: Polity, Piety and the Book of Common Prayer (London: SCM Press, 2012), Chapter 9; id., 'Prayer Book Use and Conformity', in Chapman, Clarke and Percy (eds), The Oxford Handbook of Anglican Studies, Chapter 8.

5 The Principles of Canon Law Common to the Churches of the Anglican Communion (London: Anglican Communion Office, 2008).

6 Cf. Jeffrey W. Driver, A Polity of Persuasion: Gift and Grief of Anglicanism (Eugene, OR: Cascade Books, 2014). 
church doctrine and practice. But how significant is division in the councils of the Christian church? How should we assess it? Church history shows that Christians have separated from one another since New Testament times. The councils of the early church were turbulent, and even sometimes violent, affairs. The councils that led to and followed from the reunification of the Latin Church at the Council of Constance in the early fifteenth century were unsatisfactory and some just fizzled out. Large numbers of bishops stayed away from the 2008 Lambeth Conference; but some bishops, including the Archbishop of York, absented themselves from the first LC. The recent Holy and Great Orthodox Synod was boycotted by some major Orthodox churches, including that of Russia, but that did not make it any less a 'holy' council, 'great' not in size perhaps but in historical significance for Orthodoxy. Historically, it has taken the power of emperors, beginning with Constantine the Great, to achieve near unanimity at councils (which they convened). Scripture itself and the teaching of the great divines through the centuries are emphatic that it is wrong to separate oneself from a church on grounds of perceived serious imperfections or even what one regards as scandalous. St Paul's Epistles to the Corinthians and the Galatians are conclusive on this point. Conciliarity is the art of the possible; we must do what we can with what we have got. Though we trust to the guiding power of the Holy Spirit, we are still dealing in the end with 'the crooked timber of humanity'. A council, a synod, even the Lambeth Conference, is a venture that requires ample quantities of the theological virtues of faith, hope and charity. 